the composite sample containing io per cent. sulphur this method gave 9.94 per cent. sulphur. Several duplicates made at the same time gave closely agreeing results. A number of determinations on stock tonics of varying composition gave satisfactory Iesults with closely agreeing duplicates.

The side neck tubes used in the method, shown in the figure are heavy graduated glass tubes I $6.4 \mathrm{~cm}$. tall and $3.0 \mathrm{~cm}$. in diameter with a side neck carrying a stopcock fused in about $5.0 \mathrm{~cm}$. from the bottom of the tube. The use of this side neck was found to be the most satisfactory means of drawing out the aliquot portion. When the tubes are put in the shaking machine they are closed with tight-fitting cork stoppers. No trouble has been experienced by evaporation from this source. Settling the suspended particles in the tube by means of a centrifugal machine was tried, but with only a fair amount of success and it was found better, when time will permit, to allow the tubes to stand overnight before drawing of the aliquot, thus giving a perfectly clear solution. It was found most satisfactory to draw off the aliquot into an Erlenmeyer flask of about $450 \mathrm{cc}$. capacity. Then during the oxidation with chlorine the flask is closed with a two-hole stopper. One hole is used for the tube from the generator and the other is used for a waste tube to carry off the excess of chlorine gas.

Feed and Micro-Chemical I Aboratory,

N. C. DEpartMeñ OF AGRICULTuRE, RALEIGH.

\section{A COMPARISON BETWEEN THE REFRACTION AND THE SPECIFIC GRAVITY OF MILK SERUM FOR THE DETECTION OF ADDED WATER.}

It is oftentimes very difficult for the food chemist to distinguish between honest low-standard milk and fraudulently watered milk. Various methods have been suggested, most of them being more or less unsatisfactory, owing to the time involved and diffeulty of analysis, variability of the milk constants, and the consequent unreliability of results. It has been found that the milk serum possesses a fairly constant composition, more so than the milk itself.

Different methods have been used for precipitating the casein and obtaining the serum. G. Wiegner and G. Yakuwa, of Goettingen University, ${ }^{\text {I }}$ use a dilute solution of $\mathrm{CaCl}_{2}$ to obtain the serum. The "Specific Refraction," an arbitrary constant, is then determined. Ackermann ${ }^{3}$ also uses $\mathrm{CaCl}_{2}$ to precipitate the casein and determine the refraction of the serum, claiming that it varies less than serum obtained by any other method. C. Mai and S. Rothenfusser, 3 also use the $\mathrm{CaCl}_{2}$ method, claiming they can detect four per cent. of water. The natural souring method is used by Matthes and Nuller, 4 who get very uniform results.

1 "The Extent of Refraction and Specific Gravity of Calcium Chloride Serum of Milk," Milchwirtsch. Zentr., 5, 473.

2 "The Refractometric Detection of Added Waterin Milk," Z. Nahr.Genuss, 16, 586 .

3 "The Refraction of Calcium Chloride Milk Serum," $\mathcal{Z}$. Nahr.Genuss., 18, 737 .

4 "Uber die Untersuchung des Milch Serums mit dem Zeiss'schen Eintansch-Refraktometer," $Z$. für öffent. Chem., 3, 173 .
The "Asaprol Method" is used by Baier and Neumann, but, owing to the dilution of the serum, is not regarded by some as accurate. Leach, ${ }^{r}$ and Lythgoe and Nurenberg, ${ }^{2}$ express preferences for the acetic acid method. As it is the method used in the following determinations, it is described in detail. To. Ioo cc. of milk add 2 cc. of 25 per cent. acetic acid (sp. gr. 1.035). Heat at $70^{\circ} \mathrm{C}$. for 20 minutes in a beaker covered with a watch glass on the water bath. Then cool for to minutes in ice water and filter. If the first part of the filtrate is cloudy, it will usually clear up if refiltered through the same filter paper.

The serum being obtained in the above manner, the refraction at $20^{\circ} \mathrm{C}$. is cetermined by the Zeiss immersion refractometer and the specific gravity at $5^{\circ} \mathrm{C}$. by the Westphal balance accurately graduated to four places.

As a preliminary, the refraction and fat content of different milk samples from individual cows were determined, the fat being determined by the Babcock method.

\begin{tabular}{|c|c|c|}
\hline Milk. & Refraction. & Per cent. fat \\
\hline Holstein, pure bred, ............. & . 39.8 & 3.4 \\
\hline Holstein, pure bred................ & 39.2 & 3.4 \\
\hline Holstein, pure bred................ & 43.0 & 3.0 \\
\hline Guernsey, pure bred............... & 42.5 & $\ldots$ \\
\hline Guernsey, pure bred................. & 47.3 & 4.7 \\
\hline Guernsey, pture bred..............., & 44.8 & 5.2 \\
\hline Guernsey, pure bred............... & 42.7 & 3.3 \\
\hline Red Poll, pure bred................ & 43.8 & 3.7 \\
\hline Red Poll, pure bred........, $\ldots \ldots \ldots$ & 41.9 & 6.2 \\
\hline Red Poll; pure bred................ & 43,5 & $\ldots$ \\
\hline Jersey, pure bred.................. & 44.8 & 5.0 \\
\hline Jersey, pure bred................. & 45.5 & 4.8 \\
\hline Angtis, pure brect $\ldots \ldots \ldots, \ldots \ldots \ldots \ldots$ & 43.2 & 4,2 \\
\hline Angus, pure bred.................. & 43,4 & 3.5 \\
\hline Short Hort, pure bred.............. & 44.0 & 4.1 \\
\hline Short Forn, pure bred............... & 42.0 & 4.3 \\
\hline Devont, pure bred. $\ldots \ldots \ldots \ldots \ldots \ldots \ldots$ & 43.2 & 4.6 \\
\hline Kerry, pure bred................. & 42.7 & 5.2 \\
\hline Grade Red Po11, pure bred............ & 41.3 & 4.4 \\
\hline Average $\ldots . . . \ldots \ldots \ldots \ldots \ldots \ldots \ldots$ & 43.1 & 4.3 \\
\hline Highest (Guernsey) $\ldots \ldots \ldots \ldots \ldots \ldots$ & 47.3 & (Red Poll) 6.2 \\
\hline Lowest (Holstein) $\ldots \ldots \ldots \ldots \ldots \ldots \ldots$ &.$\quad 39.2$ & (Holstein) 3.0 \\
\hline
\end{tabular}

This table shows variation in refraction from 39.2 to 4.7 .3 and also shows there is no relation between the refraction and the fat content in the sample used.

Table 2 shows that milk serum from the same cow will vary in refraction if taken at different times. Hence it would seem impossible to estimate absolutely the amount of added water in a sample even when the original source of the milk is known unless the milk came from a large herd when it might be possible as the composite serum will vary less than the individual serum.

\section{I'ABIE 2.}

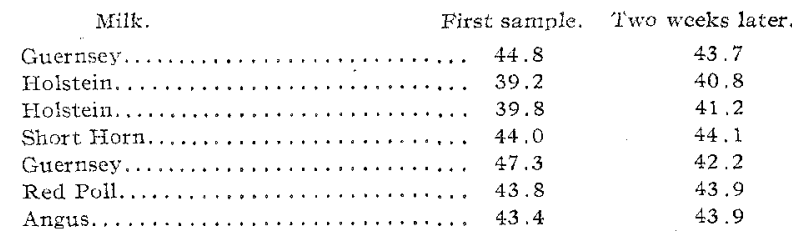

Table 3 shows milk systematically adulterated

1 "Food Inspection and Atralysis."

2 "A Comparison of Methods for the Preparation of Milk Sertum," THIs JOURNAL, 1, 38 . 
and shows the decrease in refraction and specific gravity as water is added.

\begin{tabular}{|c|c|c|}
\hline Milk "A" & $\begin{array}{l}\text { BLE } 3 . \\
\text { Refraction at } 20^{\circ} \mathrm{C} \text {. }\end{array}$ & Sp. gr. at $15^{\circ} \mathrm{C}$. \\
\hline 0 per cent. $\mathrm{H}_{2} \mathrm{O}$... & $\ldots \ldots 41.9$ & 1.0292 \\
\hline 5 per cent. $\mathrm{H}_{2} \mathrm{O} \ldots$ & $\ldots \ldots$ & 1.0269 \\
\hline 10 per cent. $\mathrm{H}_{2} \mathrm{O}$. & $\ldots \ldots \ldots$ & 1.0262 \\
\hline 15 per cent. $\mathrm{H}_{2} \mathrm{O}$. & $\ldots \ldots$ & 1.0247 \\
\hline $\begin{array}{l}20 \text { per cent. } \mathrm{H}_{2} \mathrm{O} . \\
\text { Milk "C" }\end{array}$ & $\ldots \ldots$ & 1.0233 \\
\hline 0 per cent. $\mathrm{H}_{2} \mathrm{O}$. & $\ldots \ldots$ & 1.0313 \\
\hline 5 per cent. $\mathrm{H}_{2} \mathrm{O}$... & $\ldots \ldots \ldots$ & 1.0285 \\
\hline 10 per cent. $\mathrm{H}_{2} \mathrm{O}$. & $\ldots \ldots$ & 1.0280 \\
\hline 15 per cent. $\mathrm{H}_{2} \mathrm{O}$. & $\ldots \ldots, 39.4$ & 1.0262 \\
\hline 20 per cent. $\mathrm{H}_{2} \mathrm{O}$. & $\ldots \ldots$ & 1.0251 \\
\hline $\begin{array}{l}25 \text { per cent. } \mathrm{H}_{2} \mathrm{O} . \\
\text { Milk "D" }\end{array}$ & $\ldots \ldots$ & 1.0234 \\
\hline 0 per cent. $\mathrm{H}_{2} \mathrm{O} \ldots$ & $\ldots \ldots$ & 1.0275 \\
\hline 5 pet cent. $\mathrm{H}_{2} \mathrm{O}$... & $\ldots \ldots$ & 1.0247 \\
\hline 10 per cent. $\mathrm{H}_{2} \mathrm{O}$. & $\ldots \ldots$ & 1.0237 \\
\hline 15 per cent. $\mathrm{H}_{2} \mathrm{O}$. & $\ldots \ldots$ & 1.0224 \\
\hline 20 per cent. $\mathrm{H}_{2} \mathrm{O}$. & $\ldots \ldots$ & 1.0205 \\
\hline $\begin{array}{l}25 \text { per cent. } \mathrm{H}_{2} \mathrm{O} \text {. } \\
\text { Milk " } \mathrm{E} \text { " }\end{array}$ & $\ldots \ldots$ & 1.0195 \\
\hline 0 per cent. $\mathrm{H}_{2} \mathrm{O}$.. & $\ldots \ldots$ & 1.0280 \\
\hline 5 per cent. $\mathrm{H}_{2} \mathrm{O}$. . & $\ldots \ldots$ & 1.0263 \\
\hline 10 per cent. $\mathrm{H}_{2} \mathrm{O}$. & $\ldots \ldots$ & . \\
\hline 15 per cent. $\mathrm{H}_{2} \mathrm{O}$. & $\ldots \ldots \ldots$ & 1.0243 \\
\hline 20 per cent. $\mathrm{H}_{2} \mathrm{O}$. & $\ldots \ldots \ldots$ & 1.0220 \\
\hline $\begin{array}{l}25 \text { per cent. } \mathrm{H}_{2} \mathrm{O} \text {. } \\
\text { Milk "F" }\end{array}$ & $\cdots \cdots$ & 1.0209 \\
\hline 0 per cent. $\mathrm{H}_{2} \mathrm{O}$. . & $\ldots \ldots$ & 1.0320 \\
\hline 5 per cerit. $\mathrm{H}_{2} \mathrm{O}$.. & $\ldots \ldots \ldots$ & 1.0259 \\
\hline 10 per cent. $\mathrm{H}_{2} \mathrm{O}$. & $\ldots \ldots \ldots$ & 1.0231 \\
\hline 15 per cent. $\mathrm{H}_{2} \mathrm{O}$. & $\ldots \ldots \ldots$ & 1.0219 \\
\hline $\begin{array}{l}20 \text { per cent, } \mathrm{H}_{2} \mathrm{O} \text {. } \\
\text { Milk "G" }\end{array}$ & $\ldots \ldots \ldots \quad 35.9$ & 1.0202 \\
\hline 0 per cent. $\mathrm{H}_{2} \mathrm{O}$. & $\ldots \ldots$ & 1.0306 \\
\hline 5 per cent. $\mathrm{H}_{2} \mathrm{O}$. & $\ldots \ldots \ldots 41.2$ & 1.0277 \\
\hline 10 per cent. $\mathrm{H}_{2} \mathrm{O}$. & $\ldots \ldots \ldots$ & 1.0251 \\
\hline 15 per cent. $\mathrm{H}_{2} \mathrm{O}$. & $\ldots \ldots$ & 1.0238 \\
\hline 20 per cent. $\mathrm{H}_{2} \mathrm{O}$. & $\ldots \ldots$ & 1.0220 \\
\hline 25 per cent. $\mathrm{H}_{2} \mathrm{O}$. & $\ldots \ldots$ & 1.0217 \\
\hline
\end{tabular}

The average decrease in refraction due to every Io per cent. of added water is 2.7 . The average refraction of all the pure samples used is 42.8 , the refraction of water I5.0. By a mathematical calculation it is determined that so per cent. added water should lower the refraction 2.8, corresponding very closely with the results found.

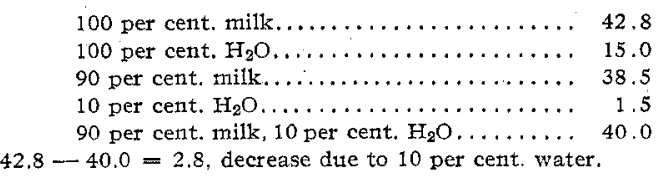

The average decrease in specific gravity due to every ro per cent. added water is $0.003 \mathrm{I}$. The average specific gravity of all pure samples is $\mathrm{I} .029 \mathrm{I}$ at $\mathrm{I} 5^{\circ} \mathrm{C}$. The specific gravity of water at $\mathrm{I} 5^{\circ} \mathrm{C}$. is $0.999 \mathrm{I}$. By calculation it is determined that so per cent. of added water should decrease the specific gravity of the serum 0.0030 , corresponding within $0.000 I$ of the results found.

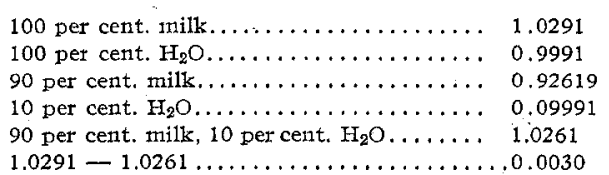

Woodman finds that ro per cent. added water lowers the specific gravity of the serum $0.003^{I}$ and J. Am. Chem. Soc., 21, 503 (1899). attempts to show that he can accurately estimate the amount of water added by taking that figure. Owing to the variability of the specific gravity of various milk serums it would not seem feasible. The pure samples examined by the author vary from 1.0270 to $x .0320$.

Radulescn and König ${ }^{2}$ both state that io per cent, of added water decreases the specific gravity of the serum $0.0003^{-0.0010}$. All other results point toward $0.003 \mathrm{I}$ as nearer the exact figure.

Most authorities take the lowest limit of refraction for pure milk serum as 39.0 regarding samples under 40.0 as suspicious. This corresponds to the results found by the author. Two Holstein samples were found under 40.0 but it is very unlikely that the composite milk of the herd, even of Holsteins, would run under 40.0. Of fourteen systematically adulterated, individual samples, 5 per cent. added water (by volume) was distinguishable in four cases, taking 39.0 as the limit of pure milk, and the milk would be regarded as "suspicious" in three more cases. ro per cent, added water was distinguished in six cases and was "suspicious" in three cases. I5 per cent. added water is distinguishable in nine cases and was "suspicious" in five cases. 20 per cent. added water was distinguishable in every sample.

I.0270 is regarded by most authorities as the low limit for the specific gravity of pure milk serum at $I 5^{\circ} \mathrm{C}$. Leach and Lythgoe ${ }^{3}$ present figures showing pure Holstein milk running as low as 1.0253 but in every case the milk itself had a specific gravity under the legal standard, 1.0290. The author has been unable to find any other authorities presenting authentic figures as low. Milks " $M$ " and " $N$ " were taken from the first milkings of Holstein cows but did not

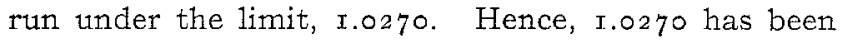
taken as the low limit for pure milk serum.

The specific gravity of the serums of the I4 individual samples (Table 3 , part) was determined on the same serum as the refraction, with the result that 5 per cent added water is distinguishable in 8 cases. Io per cent. added water is distinguishable in twelve cases and 15 per cent. of water in fourteen cases.

From the above results it would appear that the specific gravity of the serum is a much more delicate test for added water than the refraction, but owing to the fact that all authorities are not agreed as to the low limit of the specific gravity of pure milk serum, the author wotald say that it is not as reliable in all cases as the refraction. Both methods combined should furnish both a delicate and reliable guide to the detection of added water in milk. As both the methods may be used on the same serum, and as the determinations are easily made after the serum has been obtained, it appears that a combination of the two methods would insure the certain

1 "Mitl. ans dem pharm. Ins. und Laboritorium fir ang. chem. der Univ. Erlangen (1890)" 3, 93.

2 "Die Untersuchung landswirtschaftlich und gewerblich wichtiger Stoffe," Ed. (1898), 36. (1904). 
detection of added water, if in any quantity as would be used in fraudulently adulterated milk.

Omio State Unversity,

SleEter Bull.

Columbus, OHto.

\section{BOOK REVIEWS AND NOTICES.}

High Speed Steel. The Development, Nature, Treatment, and Use of High Speed Steels, together with some suggestions as to the Problems Involved in Their Use. Bx O. M. BECKER, Industrial Engineer. Cloth, pp. $v+344$. McGraw-Hill Book Company, rgio. Price, $\$ 4.00$ net.

A very good book from both practical and theoretical standpoints. In a general way the development of high-speed steel and the marvelous advance it has caused in machine operation and output are known, but one begins to understand the real magnitude of that advance as he turns the pages of this book.

The first chapters give a short history of the development of metal cutting from earliest times and methods of manufacture of the ancient steels, including the famous Wootz and Damascus brands, the later crucible, open-hearth, Bessemer and electric furnace processes, relate the discovery of Mushetthe forerunner of the high-speed steels, and the extensive experiments of Taylor and White which resulted in the wonderful steels which we have to-day. Tables are given of the chemical composition of the various types, and their properties and requirements for hardening explained according to the latest and accepted theories of metallurgy. The author has had the aid of such well-known metallurgists as Carpenter, Taylor, Stoughton, and others, in ways of suggestion, criticism, use of material, proof-reading, etc. The metallographical explanations and photomicrographs are good and make clear the theories.

The balance and larger part of the book is devoted to the practical part of the subject: the making of the steel, forging the tools, hardening, tempering, annealing, grinding, etc. The descriptions of the various types of hardening and annealing furnaces, pyrometers, machines, etc., are very complete, and apparently no usable type is omitted. Chapters are given on speeds and feeds, new requirements for machines, notes on remodeling old equipment and the problems involved. The book is well illustrated. In the appendix are given several practical tables. The volume should be of much assistance to the superintendent, metallurgist or practical tool man.
I. M. BREGOWSKY

L. W. SPRING.

Der Kautschuk und seine Prüfung. By F. W. Hinrichsen and K. MÉMMLER. 8vo, pages $x+263$. Leipzig: S. Hirzel, Igro. Price: Paper, 8 marks; eloth, 9 marks

This is, doubtless, the most comprehensive work that has been published up to date on rubber and is particularly valuable in the rubber industry to those interested in the physical testing of vulcanized rubber. A glance over the table of contents gives the best idea of the scope and thoroughness with which the work has been carried out. (I) General Part, by $\mathrm{F}, \mathrm{W}$. Hinrichsen. (A) Introduction, (B) Occurrence of Rubber, (C) Properties of the Latex, (D) Constitution of the Rubber Hydrocarbon, (E) Other Substances Associated with the Rubber Hydrocarbon in Crude Rubber, (F) Physical Properties of Crude Rubber, (G) Chemical Properties of Crude Rubber, (H) Theory of Vulcanization of Rubber, (I) Technical Handling of Rubber Materials, (J) The Properties of Vulcanized Rubber. (II) Chemical Analysis of Rubber, by F. W. Hinrichsen. (A) Analysis of Crude Rubber, (B) Analysis of Vulcanized Rubber, (C) Life Tests of Finished Rubber Articles. (III) Mechanical Testing of Rubber, by K. Memmler. (A) The Practical Carrying Out of Strength Tests on Soft Rubber. (B) Results of Strength Tests on Soft Rubber according to the Older and More Recent Publications.

The authors have compiled and arranged very excellently the work of the older and modern investigators in the field of rubber testing. Of particular interest is the attention given to the physical testing of vulcanized rubber, a division of the subject in most other works that has been given but slight attention. Nevertheless, from the standpoint of our knowledge of rubber as a material of construction it is one of the most important. The discussion of tensile tests, the pressure tests, the machines and apparatus, the elongation curves, the hysteresis curves, is very admirably written.

W. C. GrN

Die Chemie der Cellulose, By Cari, G. Schwalber. First Half. 8vo. pp. 272. Beriin: Gebrüder Borntraeger, r910.

This work is unquestionably the best on the chemistry of cellulose which has as yet been published. While it is largely bibliographic in its text, its construction and method of handling is excellent. This first half deals with cotton cellulose as a type, and considers its behavior and relation towards water, heat, alkalies, acids, salts, dyes, oxidation and reducing agents, solvents and ferments. The cellulose products produced by hydrolysis and oxidation are treated at some length. The conclusion of the first half commences the consiceration of the esters of cellulose which; as stated, are to be handled fully in the second half to be published very soon.

H. S. MORK.

Die Unterscheidung der Natürlichen und Künstlichen Seiden. By Dr. Alors Herzzog. Paper, r2mo, pp. 78 . Dresden: Theodor Steinkopf, 19 1o. Price, 75 cents.

This small pamphlet, containing fifty excellent microphotographs and illustrations, treats in a full and complete manner of the methods of differentiating the various artificial silks from each other and from the natural product. While both chemical and optical methods are given, the latter receive the greater attention. Excellent photographs are shown of the appearance of the fibers under the ultramicroscope at a magnification of 2500 . H. S. MORK. 